\title{
Erratum to: Psychological Ownership and Consumer Behavior
}

\author{
Joann Peck and Suzanne B. Shu
}

\section{Erratum to:}

J. Peck, S. B. Shu (eds.), Psychological

Ownership and Consumer Behavior, https://doi.org/10.1007/978-3-319-77158-8

The reference lists for Chapter 5 and Chapter 15 were inadvertently published with missing information for some entries. Both reference lists are now complete in the corrected versions of the chapters.

\footnotetext{
The updated online versions of these chapters can be found at https://doi.org/10.1007/978-3-319-77158-8_5 https://doi.org/10.1007/978-3-319-77158-8_15 https://doi.org/10.1007/978-3-319-77158-8
} 